\title{
Dentifrice Paste Dosage Form
}

National Cancer Institute

\section{Source}

National Cancer Institute. Dentifrice Paste Dosage Form. NCI Thesaurus. Code C42907.

A paste of mild abrasives, detergents, flavoring agents, binders, fluoride, and other active and/or inert ingredient(s). 